\title{
GMR
}

\section{Novel polymorphism in exon 1 of the melatonin receptor gene unassociated with reproductive characteristics of buffaloes in the Amazon Region}

\author{
E.M. Barbosa ${ }^{1}$, B.B. Souza ${ }^{2}$, R.C. Guimarães ${ }^{2}$, J.S.N. Azevedo ${ }^{3}$, \\ E.C. Gonçalves ${ }^{4}$, H.F.L. Ribeiro ${ }^{2}$, S.T. Rolim Filho ${ }^{2}$ and E. Silva Filho ${ }^{5}$ \\ ${ }^{1}$ Programa de Pós-Graduação em Ciência Animal, Núcleo de Ciência Animal, \\ Universidade Federal do Pará, Belém, PA, Brasil \\ ${ }^{2}$ Laboratório de Reprodução Animal, Instituto de Saúde e Produção Animal, \\ Universidade Federal Rural da Amazônia, Belém, PA, Brasil \\ ${ }^{3}$ Laboratório de Biologia Geral, Universidade Federal Rural da Amazônia, \\ Campus de Capanema, Capanema, PA, Brasil \\ ${ }^{4}$ Laboratório de Tecnologia Biomolecular, Instituto de Ciências Biológicas, \\ Universidade Federal do Pará, Belém, PA, Brasil \\ ${ }^{5}$ Laboratório de Genética Animal, Instituto de Ciências Agrárias, \\ Universidade Federal Rural da Amazônia, Belém, PA, Brasil
}

Corresponding author: E. Silva Filho

E-mail: silva.filho@ufra.edu.br

Genet. Mol. Res. 15 (2): gmr.15028309

Received December 21, 2015

Accepted February 11, 2015

Published July 15, 2016

DOI http://dx.doi.org/10.4238/gmr.15028309

\begin{abstract}
The objective of this study was to sequence part of the exon 1 in the melatonin receptor 1A gene (MTRN1A) in buffaloes to detect a novel polymorphism with which to associate reproductive characteristics, such as age at first birth and the interval between births, in buffaloes from the northeastern region of the State of Pará (Brazil). Buffalo hair samples (77) were collected from the Terra Firme region of Pará. DNA was extracted and polymerase chain reactions (PCRs) were carried out with a primer that was designed using the GenBank accession No. AY524665 reference sequence. PCR products were
\end{abstract}


purified and sequenced. After editing and analysis of the sequences, a mutation was observed at the 62nd position in exon 1 of MTRN1A $(\mathrm{T} \leftrightarrow \mathrm{C})$, which corresponded with a change in the 21 st amino acid from leucine to proline. All possible genotypes were observed, with the most common being genotype CC (0.481). The allele frequencies were $\mathrm{T}$ $=0.377$ and $\mathrm{C}=0.623$. Statistical analysis of $F_{\text {IS }}$ showed inbreeding within the sample group $\left(F_{\text {IS }}=0.397\right)$ and deviations from the HardyWeinberg equilibrium were observed $(\mathrm{P}<0.05)$. Associations between genotypes and reproductive characteristics were not significant $(\mathrm{P}$ $>0.05)$. Although the related SNP was not synonymous, there were no observable effects on the reproductive characteristics under investigation. As such, it would be ideal to detect other SNPs in exon 1 of the MTRN1A gene that can be associated with reproductive characteristics in Amazonian buffaloes.

Key words: Exon 1; SNP; Melatonin; Reproduction characteristics; Buffaloes; Amazon

\section{INTRODUCTION}

The livestock of Brazil are among the most diverse globally, owing to a significant number of breeds and genetic groups distributed across several regions, in which extensive research has been conducted over many years to determine genes associated with production and adaptability (Marques et al., 2008). There are approximately 1.3 million buffaloes in Brazil. The largest herd is in the Northern Region, which accounts for $64.1 \%$ of the national herd. The herd of buffaloes in the State of Pará specifically, accounts for 36\% of the national herd and $56.1 \%$ of the regional herd, making it the state with the largest population of buffaloes in Brazil (IBGE, 2012).

Buffalo production has increased in popularity because of the perceived economic advantage, in comparison to other domestic ruminants. The main advantage in rearing buffaloes stems from their resilience, which in turn enhances fertility, life expectancy, adaptability to various diets, production of meat and milk, and adaptability to various climatic and environmental conditions. Nevertheless, it is necessary to improve the efficiency of the methods employed in buffalo production. In order to do so, it is crucial to understand their potential in terms of production and reproduction, beyond the genetic and environmental factors that affect related characteristics (Camargo Júnior et al., 2012).

Patterns of melatonin secretion provide information on the photoperiod as it relates to brain cells, which possess the receptors necessary to control reproductive functions (Migaud et al., 2005). Melatonin receptors (MTR) are classified as MTRN1A and MTRN1B; however, only the former appears to be involved in the regulation of reproductive seasonality (Weaver et al., 1996; Dubocovich et al., 2003). MTRN1A appears to have a stimulatory effect on the reproductive axis of short day breeders. Studies on various breeds of goats and sheep have demonstrated that a polymorphism in the MTRN1A gene results in reduced seasonality in animals (Rocha et al., 2011; Zetouni et al., 2014).

The aim of the present study, therefore, was to sequence part of exon 1 in the MTRN1A gene of buffaloes in northeastern Pará (Brazil), to detect a novel polymorphism with which 
different genotypes and reproductive characteristics, such as age at first birth and the interval between births, may be associated.

\section{MATERIAL AND METHODS}

The present study was submitted to, and approved by the Animal Ethics Committee under protocol number 033/2015 at the Universidade Federal Rural da Amazônia with procedure number 23084.006321/2015-25.

\section{Samples and genotyping}

Hair was collected from 77 buffaloes from the Terra Firme region in the State of Pará. DNA extraction was carried out using the phenol:chloroform:isoamyl alcohol method (25:24:1), according to the procedure outlined by Sambrook et al. (1989). Polymerase chain reactions (PCRs) were carried out using a pair of primers that were designed based on the promoter region sequence and part of the MTRN1A exon 1 in sheep (GenBank accession No. AY524665; forward: TTTTTCATCTCTTACCATCTAG and reverse: GCGAGACGTTGAGCAGC). The final product of amplification was $810 \mathrm{bp}$.

For a final reaction volume of $15 \mu \mathrm{L}, 10 \mathrm{X}$ PCR Buffer, $1 \mathrm{mmol} \mathrm{MgCl}_{2}, 10 \mathrm{mmol}$ each deoxyribonucleotide triphosphate (dNTP), 1 U Taq DNA Polymerase (Life Technology, Brazil), 20\% Q-solution (Qiagen, Valencia, CA, USA), 50-100 ng genomic DNA, and ultrapure water were added. The initial denaturation temperature was set at $95^{\circ} \mathrm{C}$ for $10 \mathrm{~min}$; followed by 30 cycles at $94^{\circ} \mathrm{C}$ for $1 \mathrm{~min} ; 54^{\circ} \mathrm{C}$ for $1 \mathrm{~min}$; and $72^{\circ} \mathrm{C}$ for $1 \mathrm{~min}$. The final extension temperature was $72^{\circ} \mathrm{C}$ for $10 \mathrm{~min}$.

The 77 PCR products were purified with the IllustraExoProStar 1-Step enzyme (GE Healthcare, UK) following the manufacturer protocols. The purified products were sequenced using the BIG DYE kit (Life Technology) in an ABI $3500 \mathrm{XL}$ automatic DNA sequencer (Applied Biosystems, Foster City, CA, USA). The sequences were edited and aligned using the BioEdit software (Hall, 1999).

\section{Statistical analyses}

All genotypes were tabulated and the GENEPOP Version 1.2 software (Raymond and Rousset, 1995) was used to determine genotype and allele frequencies, the inbreeding coefficient $\left(F_{\text {IS }}\right)$, and the probability of the population being in Hardy-Weinberg equilibrium. The characteristics of interval between births (IBB) and age at first birth (AFB) were analyzed, assuming normal distribution across ANOVA submitted to the PROC MIXED application of the SAS 8.0 statistical package (SAS Institute, Inc., 2000), with a significance level of 0.05 . Associations between genotypes and reproductive characteristics followed the statistical model:

$$
Y i j k=X+G_{i}+F_{j}+(G x F)_{k}+e_{i j k} \quad \text { (Equation 1) }
$$

where $Y_{i j k}=$ phenotypic characteristics; = average of phenotypic characteristics; $G_{i}=$ fixed effect of the ith genotype; $F_{j}=$ fixed effect of the jth farm; $(G x F)_{k}=$ interaction effect in the kth interaction between genotype and farm; and $e_{i j k}=$ random error. 


\section{RESULTS}

A novel single nucleotide polymorphism $(\mathrm{T} \leftrightarrow \mathrm{C})$ was found at the $62 \mathrm{nd}$ position of exon 1 in the MTRN1A gene (Figure 1), which occurred at the 2nd nitrogenous base of the 21st codon that results in a change from leucine to proline (both of which are classified as apolar).

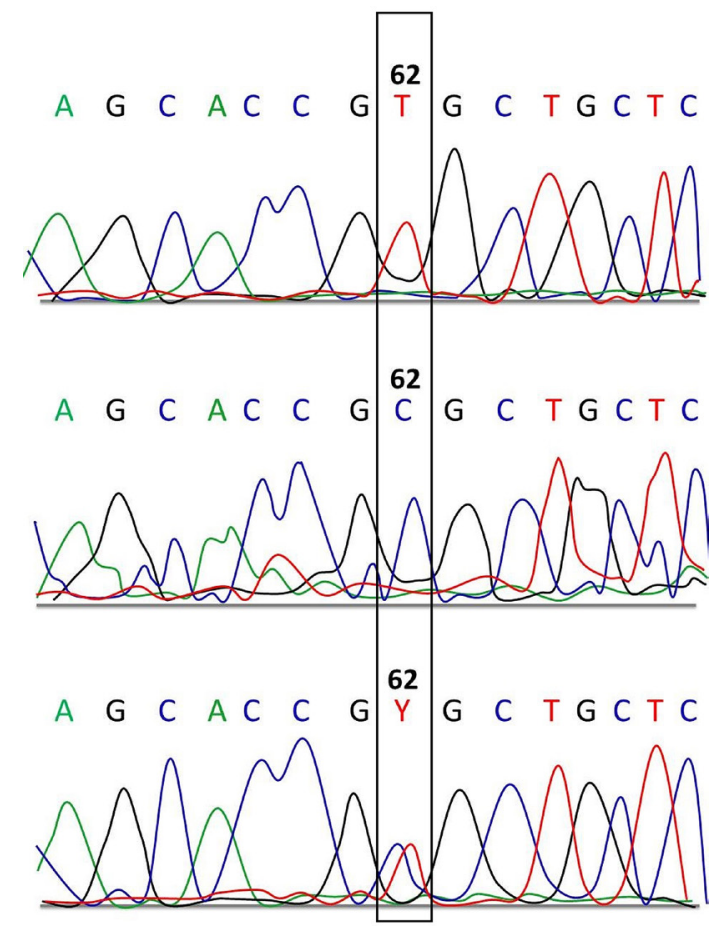

Figure 1. DNA sequencing spherogram of polymorphism $(\mathrm{T}, \mathrm{C}$, and $\mathrm{Y}=\mathrm{T}$ or $\mathrm{C})$ at the 62 nd position of exon 1 in the MTRN1A gene.

All possible genotypes (TT, TC, and CC) were observed in all 77 animals (Table 1). The allele frequencies were $\mathrm{C}=0.623$ and $\mathrm{T}=0.377 . F_{\text {IS }}$ statistical analysis revealed inbreeding within the population. Deviation from the Hardy-Weinberg equilibrium was also observed $(\mathrm{P}<0.05$; Table 1$)$. No association between genotypes and IBB or AFB was observed $(\mathrm{P}>0.05$; Table 1$)$.

\section{Table 1. Statistical analysis of the population of buffaloes.}

\begin{tabular}{l|c|c|c|c|c}
\hline Genotype & Genotype frequency & $F_{\text {IS }}$ & HWP & IBB (months) (means \pm SD) & AFB (months) (means \pm SD) \\
\hline CC & 0.481 & 0.397 & 0.001 & $16.49 \pm 4.27$ & $34.01 \pm 3.80$ \\
\hline CT & 0.286 & & & $16.05 \pm 5.04$ & $33.47 \pm 3.74$ \\
\hline TT & 0.233 & & & $16.01 \pm 3.39$ & $34.57 \pm 2.74$ \\
\hline
\end{tabular}

$F_{\text {IS }}=$ inbreeding coefficient; HWP $=$ Hardy-Weinberg probability; IBB = interval between births; $\mathrm{AFB}=$ age at first birth; $\mathrm{SD}=$ standard deviation. 


\section{DISCUSSION}

Changes in the amino acid sequence of the primary protein structure of the melatonin receptor could possibly alter its molecular conformation and thereby either diminish its efficiency or even render it inactive. Saxena et al. (2014) reported the existence of four allelic isoforms in the melatonin receptor gene of sheep and concluded that the various mutations reveal various effects in the SNPs, such as helical instability and alterations in conformational stability.

Synonymous mutations do not alter the amino acids of the protein structure and it is difficult to associate them with production traits according to Zetouni et al. (2014), who studied a synonymous SNP in exon 2 of the MTRN1A gene of buffaloes in Brazil and found no association between the SNP and reproductive characteristics. The results of Luridiana et al. (2012) for the same SNP in exon 2 of buffaloes in Italy also revealed no association with production traits or reproductive characteristics. Barbosa et al. (2016) found the same SNP in exon 2 of Amazon buffaloes and observed that this polymorphism not alter the stability of mRNA structure of gene and the respective SNP is not useful for genetic improvement, but is an excellent tool for genetic of populations.

The average AFB for buffaloes in the Amazon is 34.58 ( \pm 3.96$)$ months (Camargo Júnior et al., 2012) and the average IBB is 13.29 ( \pm 2.77) months (Bezerra Júnior et al., 2014). The population in the present study presented a similar age at first birth and a longer interval between births. When genotypes were associated with reproductive characteristics, substituting one apolar amino acid for another had no significant influence on the age at first birth or the interval between births.

Although a novel non-synonymous SNP was found in exon 1 of the MTRN1A gene, it was not sufficiently significant to be associated with reproductive characteristics of buffaloes in the Terra Firme region of the Amazon. It is therefore necessary to evaluate this novel polymorphism alongside other reproductive characteristics or production traits, in other populations and under various management systems in the Amazon and in other biomes.

\section{Conflicts of interest}

The authors declare no conflict of interest.

\section{ACKNOWLEDGMENTS}

We are very grateful for samples provided by producers from Terra Firme farms in the State of Pará. We also extend our gratitude to the Laboratório de Tecnologia Biomolecular of the Universidade Federal do Pará for laboratory facilities.

\section{REFERENCES}

Barbosa EM, Souza BB, Guimarães RC, Azevedo JSN, et al. (2016). Polymorphism in the melatonin receptor gene in buffalo populations of the Brazilian Amazon. Genet. Mol. Res. 15: gmr.15027960. DOI: 10.4238/gmr.150279601

Bezerra Júnior JS, Fraga AB, Couto AG, Barros CC, et al. (2014). Produção de leite, duração da lactação e intervalo de partos em búfalas mestiças Murrah. Rev. Caatinga 27: 184-191.

Camargo Júnior RNC, Marques JRF, Marcondes CR, Araújo CV, et al. (2012). Indices of reproductive efficiency of buffaloes of the Brazilian Eastern Amazon. Arq. Bras. Med. Vet. Zootec. 64: 796-803.

Dubocovich ML, Rivera-Bermudez MA, Gerdin MJ and Masana MI (2003). Molecular pharmacology, regulation and 
function of mammalian melatonin receptors. Front. Biosci. 8: d1093-d1108. http://dx.doi.org/10.2741/1089

Hall TA (1999). BioEdit: a user-friendly biological sequence alignment editor and analysis for Windows 95/98/NT. Nucleic Acids Symp. Ser. 41: 95-98.

IBGE (Instituto Brasileiro de Geografia e Estatística) (2012). Produção da Pecuária Municipal, Rio de Janeiro 40: 1-71.

Luridiana S, Mura MC, Pazzola M, Paludo M, et al. (2012). Association between melatonin receptor 1A (MTNR1A) gene polymorphism and the reproductive performance of Mediterranean Italian buffaloes. Reprod. Fertil. Dev. 24: 983987. http://dx.doi.org/10.1071/RD11297

Marques JRF, Costa MR, Camargo Jr RNC, Albuquerque MSM, et al. (2008). Conservação e melhoramento dos recursos genéticos animais da Amazônia brasileira. In: Anais do Congresso Brasileiro de Zootecnia, João Pessoa.

Migaud M, Daveau A and Malpaux B (2005). MTNR1A melatonin receptors in the ovine premammillary hypothalamus: day-night variation in the expression of the transcripts. Biol. Reprod. 72: 393-398. http://dx.doi.org/10.1095/ biolreprod.104.030064

Raymond M and Rousset F (1995). GENEPOP (Version 1.2): Population Genetics Software for Exact Tests and Ecumenicism. J. Hered. 86: 248-249.

Rocha RMP, Matos MHT, Lima LF, Saraiva MVA, et al. (2011). Melatonina e Reprodução Animal: Implicações na Fisiologia Ovariana. Acta Vet. Bras 5: 147-157.

Sambrook J, Fritsch EF and Maniatis T (1989). Molecular Cloning, A Laboratory Manual. 2nd edn. Cold Spring Harbor Laboratory Press, New York.

SAS Institute, Inc. (2000). SAS/STAT ${ }^{\circledR} 8.0$ User’s Guide. SAS Institute Inc., Cary.

Saxena VK, Jha BK, Meena AS and Naqvi SMK (2014). Sequence analysis and identification of new variations in the coding sequence of melatonin receptor gene (MTNR1A) of Indian Chokla sheep breed. Meta Gene 2: 450-458. http:// dx.doi.org/10.1016/j.mgene.2014.05.005

Weaver DR, Liu C and Reppert SM (1996). Nature's knockout: the Mellb receptor is not necessary for reproductive and circadian responses to melatonin in Siberian hamsters. Mol. Endocrinol. 10: 1478-1487.

Zetouni L, de Camargo GM, da Silva Fonseca PD, Cardoso DF, et al. (2014). Polymorphisms in the MTRN1A gene and their effects on the productive and reproductive traits in buffaloes. Trop. Anim. Health Prod. 46: 337-340. http:// dx.doi.org/10.1007/s11250-013-0493-1 